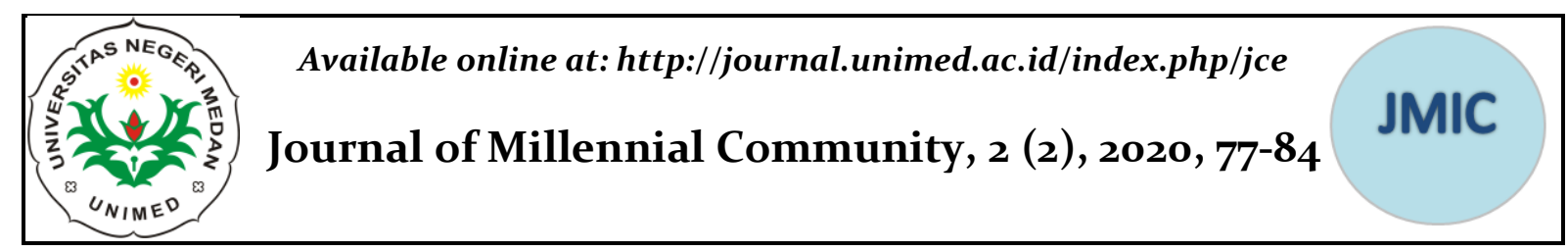

\title{
Kompetensi Tutor Dan Manajemen Pendidikan Pada Pkbm Hanuba Dalam Mencapai Tujuan Pembelajaran
}

\author{
Jubaidah Hasibuan \\ Prodi Pendidikan Masyarakat, Universitas Negeri Medan \\ Email: jubaidahhasibuano2@gmail.com
}

\begin{abstract}
Abstrak
Kompetensi yang dimiliki oleh pendidik atau tutor di PKBM Hanuba belum seutuhnya ada didalam diri mereka, masih adanya tutor yang mengajar tidak sesuai dengan bidangnya membuat transfer of knowledge dan penguasaan materi kurang maksimal dan optimal. Penelitian ini bertujuan untuk mengetahui 1) kesenjangan antara teori profesi kependidikan dengan profesi tutor di PKBM Hanuba; 2) bagaimana penerapan 4 kompetensi pendidik pada setiap tutor PKBM Hanuba; dan 3) bagaimana sistem manajemen pendidikan pada PKBM Hanuba. Penelitian ini menggunakan metode kualitatif. Lokasi penelitian di PKBM Hanuba Kota Medan. Pengumpulan data dilakukan dengan metode observasi, wawancara dan dokumentasi. Teknik pemeriksaan keabsahan data menggunakan teknik triangulasi sumber dan teknik. Analisis data melalui pengumpulan data, reduksi data, penyajian data, penarikan kesimpulan/verifikasi data.
\end{abstract}

Kata Kunci: Kompetensi, Tutor, Manajemen Pendidikan

\section{Tutor Competencies and Education Management at Pkbm Hanuba in Achieving Learning Goals}

\begin{abstract}
The competencies possessed by educators or tutors at PKBM Hanuba are not yet completely within them, there are still tutors who teach not in accordance with their fields making the transfer of knowledge and mastery of material less optimal and optimal. This study aims to determine 1) the gap between the theory of the educational profession and the tutor profession in PKBM Hanuba; 2 ) how to apply the 4 competences of educators to each Hanuba PKBM tutor; and 3) what is the education management system at PKBM Hanuba. This study uses a qualitative method. The research location is PKBM Hanuba Medan City. The data were collected by means of observation, interviews and documentation. The technique of checking the validity of the data used triangulation techniques. Data analysis through data collection, data reduction, data presentation, drawing conclusions / data verification.
\end{abstract}

Keywords: Competence. Tutor. Education Management

\section{PENDAHULUAN}

Pendidikan merupakan usaha sadar dan terencana yang dilakukan sebagai upaya menumbuhkan dan mengembangkan potensi-potensi peserta didik sesuai dengan nilai dan norma yang ada di dalam masyarakat. Peran pendidikan begitu penting karena dengan pendidikan manusia dapat melakukan segala hal termasuk dalam meningkatkan taraf hidupnya. Pendidikan itu merupakan investasi jangka panjang bagi manusia untuk memenuhi kebutuhannya. Keberhasilan pendidikan dapat dilihat dari individu itu sendiri sejauh mana individu 
tersebut bermanfaat di lingkungan masyarakat. Di Indonesia sendiri terdapat 3 jalur pendidikan yakni pendidikan formal, nonformal dan informal seperti tercantum dalam UU No 20 Tahun 2003 Pasal 13 Ayat (1) "Jalur Pendidikan terdiri atas pendidikan formal, nonformal, dan informal yang dapat saling melengkapi dan memperkaya."

Ketiga jalur pendidikan tersebut merupakan pelayanan pendidikan yang diberikan kepada masyarakat untuk dapat mengeyam pendidikan. Sudjana (2010) mengatakan bahwa pendidikan nonformal merupakan setiap kegiatan yang terorganisir dan sistematis, diluar sistem pesekolahan yang mapan, dilakukan secara mandiri atau merupakan bagian penting dari kegiatan yang lebih luas, yang sengaja dilakukan untuk melayani peserta didik tertentu dalam mencapai tujuan belajarnya. Salah satu program dari pendidikan nonformal yaitu program pendidikan kesetaraan. Pendidikan kesetaraan ini ditunjukan bagi seluruh masyarakat yang tidak mendapat kesempatan untuk mengenyam pendidikan di sekolah atau pendidikan formal, dimana berbagai faktor yang mempengaruhinya diantaranya yaitu putus sekolah, status ekonomi keluarga, faktor geografis, D.O (Drop Out), bahkan untuk kebutuhan kerja dan lain sebagainya. Pada tahun 2015 saja angka D.O SMP/MTs di Indonesia mencapai 85.000 orang di seluruh propinsi berdasarkan data dari Pusat Data Statistik Pendidikan (PDSP) Kementerian Pendidikan dan Kebudayaan. Sedangkan Data angka D.O (Drop Out) SLTA setiap tahun pelajaran mengalami peningkatan. Hasil pendataan pada tahun pelajaran 2014/2015 sebanyak 68.219 peserta didik. (Dirjen PAUD dan Dikmas) berdasarkan data tersebut pendidikan kesetaraan mampu memberikan kontribusi yang cukup besar dalam upaya mencerdaskan kehidupan bangsa.

Dalam proses belajar seorang pendidik berperan penting untuk mewujudkan tujuan pembelajaran, dan memberikan materi pembelajaran, selain itu pendidik dituntut untuk memberikan pengajaran yang baik kepada peserta didik sehingga peserta didik tidak hanya mengerti tentang materi yang disampaikan melainkan mereka mampu memahami serta mengaplikasikan di kehidupannya. Pengajaran yang baik dapat diperoleh dengan memberikan rasa nyaman kepada peserta didik, karena pengajaran yang menyenangkan akan memberikan ingatan yang berkepanjangan. Menurut Undangundang nomor 14 tahun 2005 tentang Guru dan Dosen yang dimaksud dengan guru adalah pendidik profesional dengan tugas utama mendidik, mengajar, membimbing, mengarahkan, melatih menilai dan mengevaluasi peserta didik pada pendidikan anak usia dini jalur pendidikan formal, pendidikan dasar sampai pendidikan menengah keatas. Pendidik yang profesional akan mampu mencetak anak bangsa yang berkualitas. Kunci yang harus dimiliki oleh setiap pengajar adalah kompetensi. Kompetensi adalah seperangkat ilmu serta ketrampilan mengajar guru di dalam menjalankan tugas profesionalnya sebagai seorang guru sehingga tujuan dari pendidikan bisa dicapai dengan baik. Sementara itu, standard kompetensi yang tertuang ada dalam peraturan Menteri Pendidikan Nasional mengenai standar kualifikasi akademik serta kompetensi guru dimana peraturan tersebut menyebutkan bahwa guru profesional harus memiliki 4 kompetensi guru profesional yaitu kompetensi pedagogik, kompetensi sosial, kompetensi intelektual serta profesional. Selain pendidik, hal lain yang penting dalam keberlangsungan pendidikan adalah manajemen pendidikan. Dimana manajemen pendidikan merupakan suatu proses untuk mengkoordinasikan berbagai sumber daya pendidikan seperti guru, sarana dan prasarana pendidikan seperti perpustakaan, laboratorium, dsb untuk mencapai tujuan dan sasaran pendidikan. Yaitu mencerdaskan kehidupan bangsa dan mengembangkan manusia seutuhnya, yaitu manusia yang beriman dan bertaqwa terhadap Tuhan Yang Maha Esa dan berbudi pekerti luhur, memiliki pengetahuan dan keterampilan, kesehatan jasmani dan rohani, kepribadian yang mantap dan mandiri serta rasa tanggung jawab kemasyarakatan dan kebangsaan. PKBM HANUBA sebagai salah satu lembaga pendidikan yang menyelenggarakan program 
pendidikan kesetaraan paket $\mathrm{A}, \mathrm{B}$ dan $\mathrm{C}$. Tenaga pendidik yang ada di PKBM HANUBA masih ada yang mengajar tidak sesuai bidangnya sehingga transfer of knowledge tidak berjalan dengan optimal. Walaupun sebelum melakukan proses mengajar, pendidik berusaha memahami apa yang ia ajarkan sebelum direalisasikan ke peserta didik, dan pendidik sendiri tidak merasa kesulitan pada saat menyampaikan materi kepada warga belajar, karena pelajaran tersebut juga sudah pernah ia pelajari pada bangku sekolah yang ia tempuh tetapi tetap saja transfer of knowledge yang ada tidak optimal dan maksimal.

\section{METODE}

Penelitian ini dilakukan menggunakan metode deskriptif kualitatif untuk memperoleh gambaran mengenai peristiwa dan fakta yang ada tentang kompetensi pendidik dan manajemen pendidikan di PKBM Hanuba Kota Medan. Lokasi penelitian adalah di PKBM Hanuba Jl. A.H. Nasution Gg. Jadi No. 18 B, Kwala Bekala, Kota Medan. Subjek penelitian ini adalah 2 orang tutor dan pengelola PKBM Hanuba.

Metode pengumpulan data dilakukan dengan metode observasi adalah pengumpulan data dengan melakukan pengamatan, meliputi kegiatan pemuatan perhatian terhadap suatu objek dengan menggunakan seluruh alat indra (Suharsimi Arikunto 2010: 199). Observasi digunakan untuk mengetahui bagaimana kondisi dalam kelas serta lingkungan PKBM, sikap dan antusias peserta didik, strategi tutor dalam mengajar serta manajemen pendidikan PKBM tersebut. Wawancara (interview) yaitu sebuah dialog yang dilakukan oleh pewawancara untuk memperoleh informasi dari terwawancara. Wawancara digunakan peneliti untuk menilai keadaan seseorang yaitu pendidik dan pengelola PKBM. Dokumentasi merupakan metode pengumpulan data melalui peninggalan tertulis, seperti arsip-arsip, dan termasuk buku-buku tentang pendapat, teori dan lainnya yang berhubungan dengan masalah penelitian (S. Margono 2005: 181).
Keabsahan data dalam penelitian ini menggunakan teknik triangulasi data untuk membuktikan kebenaran data. Analisis data dilakukan saat pengumpulan data berlangsung, dan setelah selesai pengumpulan data dalam periode tertentu. Pada saat wawancara sudah melakukan analisis terhadap jawaban informan. Pengumpulan data dilakukan dengan cara mencari data yang diperlukan terhadap berbagai bentuk dan jenis data yang ada di lapangan, setelah itu melaksanakan pencatatan data di lapangan. Memperoleh data melalui observasi dan wawancara dengan tutor dan pengelola PKBM. Mereduksi data merupakan merangkum, memilih hal-hal yang pokok, memfokuskan pada hal-hal yang penting, dicari tema polanya serta membuang yang tidak perlu. Data yang telah direduksi akan memberikan gambaran yang lebih jelas, dan mempermudah peneliti untuk melakukan pengumpulan data selanjutnya dan mencari apabila diperlukan (Sugiyono 2010: 338). Menyajikan data atau mendisplay data dalam penelitian kualitatif dilakukan dalam bentuk uraian singkat, bagan, hubungan, antar kategori, dan sejenisnya. Data yang sudah dipilih dan difokuskan, dan saling berhubungan sehingga memperjelas hasil penelitian, kemudian dideskripsikan secara sederhana dan sistematis serta dapat memberikan gambaran-gambaran yang lebih jelas tentang hasil penelitian di lapangan tentunya di PKBM Hanuba Kota Medan.

\section{HASIL DAN PEMBAHASAN}

\section{KOMPETENSI TUTOR}

Setelah kami melakukan observasi dan wawancara pada PKBM Hanuba, kami melihat kompetensi tutor di PKBM tersebut berdasarkan Standar Kompetensi Tutor yang terbagi menjadi 4:

1) Kompetensi Pedagogik

Sesuai dengan jurnal Analisis Kompetensi Tutor Pendidikan Kesetaraan Program Paket B Di Provinsi Jawa Timur yang menyatakan bahwa kompetensi pedagogik adalah kemampuan yang berkenaan dengan pemahaman terhadap peserta didik atau 
warga belajar dan pengelolaan pembelajaran yang partisipatif dan dialogis. Secara substantif, kompetensi ini mencakup kemampuan pemahaman terhadap peserta didik, perancangan dan pelaksanaan pembelajaran, evaluasi hasil belajar, dan pengembangan peserta didik untuk mengaktualisasikan berbagai potensi yang dimilikinya. Pada PKBM Hanuba,tutor yang mengajar melaksanakan kegiatan pembelajaran untuk warga belajarnya dengan merencanakan program apa saja yang cocok sebagai pembekalan keterampilan diluar daripada mengejar paket kesetaraan, dengan cara mengidentifikasi mengenai keterampilan apa yang digemari, bermanfaat serta dapat menguntungkan di satu sisi dan juga dirancang sedemikian rupa dengan menghadirkan inovasi-inovasi baru pada setiap programnya agar warga belajarnya tidak merasa bosan dan monoton akan satu hal. Dan juga pada salah satu tutor di PKBM tersebut yang kami wawancarai, bahwasannya ia mempunyai kemampuan untuk memahami peserta didiknya dari aspek kognitif yang berdampak kepada gaya belajarnya, seperti tutor tersebut yang paham bahwa ada seorang anak atau warga belajar yang ketika belajar ia tidak dapat diajarin dengan suara yang keras, maka disitulah tutor memahami karakteristik warga belajarnya sehingga dapat menyesuaikan bagaimana cara mengajar anak tersebut. Akan tetapi, menurut tutor sendiri tidak terjadi kesulitan dalam mengaplikasikannya pada pembelajaran (mengajar), karena tutor merasa dengan mempelajari materi sebelum mengajar (walaupun bukan bidangnya) akan tetapi hal itu masih dapat dipahami.

\section{Kompetensi Kepribadian}

Pada jurnal Analisis Kompetensi Tutor Pendidikan Kesetaraan Program Paket B Di Provinsi Jawa Timur dinyatakan bahwa kompetensi kepribadian berkaitan dengan kemampuan personal yang mencerminkan kepribadian yang mantap, stabil, dewasa, arif, dan berwibawa menjadi teladan bagi peserta didik atau warga belajar, serta berakhlak mulia. Salah satu yang menjadi kriteria dalam kompetensi kepribadian adalah berakhlak mulia, sudah tercermin di diri para pendidik PKBM HANUBA, mereka sukarela mengajar, mementingkan layanan diatas kepentingan pribadi, mereka beranggapan bahwa membantu orang lain lebih penting daripada harus memikirkan materi yang didapat. Dan hal itu sangat mulia dan dapat menjadi teladan bagi peserta didik/WB seperti yang dikatakan dalam jurnal Analisis Kompetensi Tutor Pendidikan Kesetaraan Program Paket B Di Provinsi Jawa Timur.

\section{Kompetensi Sosial}

Pada jurnal Analisis Kompetensi Tutor Pendidikan Kesetaraan Program Paket B Di Provinsi Jawa Timur menyatakan bahwa kompetensi sosial berkenaan dengan kemampuan pendidik sebagai bagian dari masyarakat untuk berkomunikasi dan bergaul secara efektif dengan peserta didik atau warga belajar, sesama pendidik, tenaga kependidikan, orang tua atau wali peserta didik atau warga belajar, dan masyarakat sekitar. Keadaan di PKBM HANUBA, kemampuan tutor untuk berkomunikasi dengan warga belajar, terlihat dari bagaimana cara mereka melayani warga belajar, welcome dengan warga belajar, menyesuaikan cara mereka berkomunikasi yang sesuai dengan warga belajar itu sendiri sehingga nyaman untuk belajar. Kemudian untuk ke sesama pendidik, pada saat kami melakukan penelitian, terlihat betapa terjalin sangat baiknya komunikasi antar pendidik atau tutor nya karena yang terlihat pada saat kami melakukan penelitian adalah terjalin kedekatan dan komunikasi yang baik antar pendidiknya. Dan komunikasi antara pendidik dengan orang tua/wali peserta didik juga berjalan dengan baik, terlihat dari cara mereka melayani orangtua/wali peserta didik yang menelpon untuk menanyakan ijazah dengan sopan santun.

\section{Kompetensi Profesional}

Pada jurnal Analisis Kompetensi Tutor Pendidikan Kesetaraan Program Paket B Di Provinsi Jawa Timur menyatakan bahwa kompetensi profesional adalah kemampuan yang berkenaan dengan penguasaan materi 
pembelajaran secara luas dan mendalam yang mencakup penguasaan substansi isi materi kurikulum, mata pelajaran di satuan PNF, dan substansi keilmuan yang menaungi materi kurikulum tersebut, serta menambah wawasan keilmuan sebagai PTK-PNF. Dan pada PKBM Hanuba sendiri, para tutornya terkhusus tutor yang kami wawancarai sebagai narasumber, tidak mengajar sesuai bidangnya, sehingga bagaimana bisa ia menguasai materi secara luas dan mendalam, karena tutor tersebut hanya memahami materi ketika ia akan mengajarkan materi tersebut. Dengan ia mempelajari materi tersebut terlebih dahulu, dalam waktu yang singkat pemahaman materi tidak dapat seluas dan mendalam, berbeda dengan ketika memang itu adalah bidangnya.

\section{MANAJEMEN PENDIDIKAN PKBM HANUBA}

Menurut Soetopo menyatakan bahwa manejemen kesiswaan adalah Soetopo (2006:34) menyatakan bahwa manajemen kesiswaan adalah: "suatu penataan atau pengaturan segala aktivitas yang berkaitan dengan peserta didik tersebut dari mulai masuknya peserta didik sampai dengan keluarnya peserta didik tersebut dari suatu sekolah atau lembaga." Dari teori diatas dengan hasil penelitian Kami di PKBM HANUBA adalah bahwa PKBM HANUBA sudah melakukan Manejemen Kesiswaan karna didalam PKBM siswa dilakukan pembinaan dimana PKBM HANUBA ikut serta membantu dalam mencari bakat dan minat peserta didiknya.

Perencanaan Manajemen Kesiswaan ini menyangkut dengan perencaan kegiatan apa yang dilakukan PKBM HANUBA dengan peserta didik yang disesuaikan dengan keinginan atau kebutuhan peserta didik tersebut. Selain Manjemen kesiswaan PKBM HANUBA juga mengunakkan Manajemen Sarana Prasarana, yaitu Menurut Mulyasa (2003: 49), sarana pendidikan adalah peralatan dan perlengkapan yang secara langsung dipergunakan dan menunjang proses pendidikan, khususnya proses belajar mengajar, seperti gedung, ruangan kelas, meja, kursi, serta alat-alat dan media pengajaran. Menurut Hasil penelitian kami PKBM HANUBA sudah melakukan manajemen sarana prasana dimana PKBM HANUBA melengkapi perealatan dan perelngakapan untuk menunjang kegiatan pembelajaran berlangsung baik alat-alat maupun pendidik nya. Sehingga sarana dan prasarana merupakan faktor pendukung yang sangat penting dalam dunia pendidikan selain tenaga pendidik. Pendidikan tidak akan pernah bisa berjalan dengan baik tanpa adanya sarana dan prasarana yang memadai. Sarana dan prasarana tidak akan dapat terpenuhi tanpa adanya manajemen yang dijalankan dalam lembaga pendidikan yang terkait dan dengan adanya manajemen sarana dan prasarana pendidikan akan berdaya untuk proses pembelajaran. Sebelum melengkapi sarana dan prasarana PKBM HANUBA biasanya melakukan perencanaan sarana dan prasarana pendidikan pertama melalui analisis kebutuhan dilakukan dengan menganalisis dan mengevaluasi sarana dan prasarana apa saja yang diperlukan untuk mendukung proses pembelajaran di dalam kelas maupun di luar kelas. Hal tersebut secara garis besar selaras dengan teori yang dikemukakan oleh Kompri (2014) intinya menyatakan bahwa analisis kebutuhan sarana dan prasarana pendidikan dilakukan pada proses perencanaan dan analisis tersebut menyangkut pada kebutuhan pada sarana dan prasarana dalam pembelajaran biasanya yang melakukan analisis kebutuhan adalah para pendidik di PKBM HANUBA.

Dalam analisis terdapat satu langkah yang sangat penting yaitu evaluasi. Evaluasi mempunyai tujuan untuk mengetahui kualitas dan kuantitas sarana dan prasarana pendidikan. Perencanaan sarana dan prasarana pendidikan yang kedua adalah analisis pembiayaan dilakukan untuk memenuhi kebutuhan pembelian sarana dan prasarana dan untuk meminimalisir penggunaan dana yang tidak tepat sasaran. Hal tersebut senada dengan teori yang diungkapkan oleh Gunawan dan Benty (2017) intinya menyatakan bahwa dalam proses perencanaan sarana dan prasarana pendidikan harus memperhatikan estimasi biaya yang tersedia di lembaga sekolah. Selain 
senada dengan teori yang diungkapkan oleh Gunawan dan Benty temuan diatas juga didukung dengan temuan Idris (2013) intinya menyatakan bahwa penyedian sarana dan prasarana pendidikan secara umum melalui dana dari pemerintah. Ketersediaan dana pendidikan sangatlah penting dalam setiap lembaga terutama lembaga pendidikan. Dana yang tersedia pada lembaga pendidikan diperguankan untuk memenuhi kebutuhan sekolah salah satunya dalam pemenuhan sarana dan prasarana pendidikan.

Dana yang diberikan pemerintah tidak mampu untuk memenuhi kebutuhankebutuhan yang secara keseluruhan. Selanjutnya dari hasil penelitian kami PKBM HANUBA juga melakukan manajemen keuangan .Manjemen keuangan pendidikan atau disebut juga dengan pembiayaan pendidikan adalah sejumlah kegiatan yang berhubungan dengan pengadaan keuangan, pemanfaatan keuangan hingga pertanggung jawaban keuangan dengan harapan tercapainya tujuan pendidikan secara efektif dan efisien. Manajemen keuangan berarti pengurusan dan pertanggung jawaban dalam menggunakan keuangan baik kepada masyarakat, pemerintah daerah, maupun kepada pemerintah pusat, dimulai dari perencanaan,pengorganisasian, pelaksanaan, sampai kepengawasan dan pertanggung jawaban keuangan. Sebelum PKBM HANUBA melakukan suatu kegiatan PKBM HANUBA biasanya melakukan perencanaan terlebih dahulu seperti kegiatan apa yang mereka ingin lakukan,lalu di organisasikan, setelah semua sudah sesuai baru PKBM HANUBA melakukan pelaksanaan dengan pertanggung jawaban atas kegiatan mereka.PKBM HANUBA juga mengatakan fungsi dari Manajemen Keuangan ini cukup banyak yaitu: dapat menyusun rencana sekolah, mengevaluasi kemajuan serta melakukan upaya korektif yang diperlukan, untuk mengatur aktivitas sekolah dan menetapkan anggaran untuk tahun berikutnya. Selanjutnya kita akan membahas tentang Manajemen Kurikulum di PKBM HANUBA,

UU. No. 20 tahun 2003 tentang Sistem Pendidikan Nasional menyebutkan bahwa, kurikulum adalah seperangkat rencana dan pengaturan mengenai tujuan, isi, dan bahan pelajaran serta cara yang digunakan sebagai pedoman penyelenggaraan kegiatan pembelajaran untuk mencapai tujuan tertentu.

Manajemen kurikulum adalah suatu system pengelolaan kurikulum yang kooperatif, komperhensif, sistemik, dan sistematik dalam rangka mewujudkan ketercapaian tujuan kurikulum. Oleh karena itu, otonomi yang diberikan pada lembaga pendidikan dalam mengelola kurikulum secara mandiri dengan memprioritaskan kebutuhan dan ketercapaian sasaran dalam visi dan misi lembaga pendidikan tidak mengabaikan kebijaksanaan nasional yang telah ditetapkan. Dari hasil penelitian kami di PKBM HANUBA bahwa PKBM HANUBA melaksanakan Manejemen kurikulum dimana PKBM HANUBA melakukan sistem pengelolaan kurikulum yaitu bersifat kerja sama, pembelajaran yang meliputi banyak hal yaitu Ilmu Pengetahuan, Budi Pekerti, Akhlak, Karakter, Kreativitas, Inovatif. Dan memiliki aturan di PKBM HANUBA itu sendiri. PKBM HANUBA juga melakukan manajemen sekolah dengan hubungan masyarakat. Sekolah dan masyarakat adalah lingkungan hidup yang tidak dapat dipisahkan. Sekolah sebagai tempat belajar sedangkan lingkungan masyarakat merupakan tempat implikasi dari proses pendidikan dan pengajaran disekolah. Apa dan bagaimana belajar disekolah selalu dikaitkan dengan kegunaanya bagi peningkatan hidup dan kehidupan dimasyarakat. Lingkungan pendidikan adalah segala sesuatu yang ada dan terjadi dalam proses pendidikan, karena kelompok bendabenda atau lingkungan pendidikan ikut berperan serta dalam usaha mengembangkan dirinya.

Dalam hal ini manajemen pendidikan menaruh perhatian kepada lingkungan yang berwujud manusia yaitu masyarakat dalam mewujudkan suatu proses pendidikan yang bermutu. Sedangkan untuk manejemen ketenagaan PKBM HANUBA biasanya melakukan rekrtumen anggota, lalu diorientasi jika sudah diorientasi maka dilakukan pelatihan dan penempatan. 


\section{SIMPULAN}

Kompetensi pedagogik yang dimiliki oleh tutor di PKBM Hanuba terlihat sudah maksimal dari cara tutor memahami gaya belajar dan karakteristik peserta didiknya. Kompetensi kepribadian yang tercermin dari diri tutor adalah pribadi yang mantap, stabil, dewasa, arif dan berwibawa serta menjadi teladan bagi warga belajar, dengan mengajar sepenuh hati dan hati yang ikhlas maka itu sudah lebih dari cukup mencerminkan pribadi yang dapat menjadi teladan dan berakhlak mulia. Kompetensi sosial yang dimiliki oleh tutor PKBM Hanuba sudah terlihat maksimal dimana tutor dapat melayani dengan memberikan kenyamanan belajar, berkomunikasi dengan warga belajar, maupun dengan orang tua warga belajar. Dan kompetensi profesional yang dimiliki tutor yang berkenaan dengan penguasaan materi pembelajaran secara luas dan mendalam dirasa kurang optimal karena bidang yang diajarkan tidak sesuai dengan bidang yang diampuh.

Manajemen Pendidikan yang diterapkan di PKBM Hanuba sudah cukup diterapkan dengan baik mulai dari manajamen kesiswaan yang disesuaikan dengan keinginan atau kebutuhan peserta didik tersebut. Manajemen sarana prasana dimana PKBM Hanuba melengkapi peralatan dan perlengakapan untuk menunjang kegiatan pembelajaran berlangsung baik alatalat maupun pendidiknya. Manajemen keuangan pendidikan atau disebut juga dengan pembiayaan pendidikan. Manejemen kurikulum dengan melakukan sistem pengelolaan kurikulum yaitu bersifat kerja sama, pembelajaran yang meliputi banyak hal yaitu Ilmu Pengetahuan, Budi Pekerti, Akhlak, Karakter, Kreativitas, Inovatif. Selain itu di PKBM HANUBA menerapkan manajemen sekolah dengan hubungan masyakrakat Sekolah dan masyarakat adalah lingkungan hidup yang tidak dapat dipisahkan, manejemen ketenagaan PKBM.

\section{DAFTAR PUSTAKA}

Adrianto,Lambok Amran. (2010). Kinerja Tutor Dalam Proses Pembelajaran Paket C. Vol. 5, No. 2. Hlm 120-134.

Bachtiar,M Yusri. (2016). Pendidik dan Tenaga Kependidikan. Vol. 6, No. 3. Hlm 196- Page $\mid 83$ 202.

Fadhilah,dkk.(2014).Manajemen Kesiswaan pada Madrasah Tsnawiyah Negeri Cot Gue Kabupaten Aceh Besar. Vol. 2, No. 1. Hlm 89-96.

Fitria,Bella Okta,dkk. (2014). Manajemen Pendidik Dan Tenaga Kependidikan Dalam Meningkatkan Mutu Pendidikan.

Hanizar, Dewi Siti,dkk. (2014). Pengelolaan Program Pusat kegiatan Belajar Masyarakat. Vol. 3, No. 11. Hlm 1-13.

Hardjono, dkk. (2016). Model Pemberdayaan Pusat Kegiatan Belajar Masyarakat dalam Pengelolaan Program Pendidikan Kesetaraan Berbasis Life Skills dan Kewirausahaan. Vol. 1, No. 2. Hlm 1-14.

Irwan, M. (2017). Evaluasi Program Pelatihan Pengolahan Limbah Kertas Semen pada Pusat Kegiatan Belajar Masyarakat (PKBM) Cahaya Kota Binjai. Jurnal Pendidikan dan Pemberdayaan Masyarakat, 4(2), 121-132.

Kasmawati. (2019). Implementasi Perencanaan Pendidikan dalam Lembaga Pendidikan Islam. Vol. 3, No. 1, 2019. Hlm 138-147.

Komariah,N. Jurnal Al-Afkar. (2018). Konsep Manajemen Keuangan Pendidikan. Vol. 6, No.1, Hlm 67-94.

M.Feralys Novauli. (2015). Kompetensi Guru Dalam Peningkatan Prestasi Belajar Pada SMP Negeri Dalam Kota Banda Aceh. Vol. 3, No.1, Hlm 45-67.

Muzaqi,Moh.dkk. (2008). Analisis Kompetensi Tutor Pendidikan Kesetaraan Program Paket B di Provinsi Jawa Timur. Vol. 3, No.1, Hlm 5-15.

Nasbi,Ibrahim. (2017). Manajemen Kurikulum : Sebuah Kajian Teoritis. Vol. 1, No.2, Hlm 318-330.

Nasrudin,dkk. (2018). Manajemen Sarana dan Prasarana Pendidikan Dalam 


\section{Journal of Millennial Community, 2 (2), September 2020}

Jubaidah Hasibuan

Pembelajaran di SD. Vol. 13, No.1, Hlm 15-23.

\section{PROFIL SINGKAT}

Penulis Jubaidah Hasibuan merupakan Civitas Akademika Pendidikan Masyarakat Universitas Negeri Medan. 